Natalia Arce', Roger Moya ${ }^{2}$

\title{
WOOD CHARACTERIZATION OF ADULT CLONES OF Tectona grandis GROWING IN COSTA RICA
}

Keyworks:

Tectona grandis

clones

heartwood

specific gravity

wood color

CIE Lab

Histórico:

Recebido 20/08/2013

Aceito 27/02/20 I 5

Palavras chave:

Tectona grandis

Clone

cerne

medula

massa especifica

cor da madera

CIE Lab

Correspondence: rmoya@itcr.ac.cr
ABSTRACT: Tectona grandis is an important wood in the commercial market due to its excellent workability, durability and aesthetic characteristics. Therefore, it is important to improve the conditions of reproduction and development in commercial plantations using clone reproduction, in order to produce trees with better wood quality. In this study we analyzed the general properties, physical properties and color of 20 adult teak clones (fifteen-year-old) from the area of Guanacaste, Costa Rica. It was found that at 15 years, the clones have a diameter which varies from $19.82 \mathrm{~cm}$ to $30.13 \mathrm{~cm}$, the percentage of heartwood ranges from 49.76 to $60.02 \%$, and that these values are similar to those found in the literature. In regards to the physical properties, it was found that the specific gravity ranges from 0.45 to $0.60 \mathrm{~g} \cdot \mathrm{cm}^{-3}$, the green moisture content varies from $70 \%$ to $110.6 \%$. In the color properties, it was found that $L^{*}$ values ranged from 48 to 59 , a* 7 to 9.5 and b * from 20.5 to 26.3. Likewise it was determined that the color change $\left(\Delta \mathrm{E}^{*}\right)$ compared to commercial wood color, is commonly categorized as perceptible in all clones. However, three of the clones studied have a darker color and reddish wood which indicates a color more desirable to the end user.

\section{PROPRIEDADES DA MADEIRA DE CLONES ADULTOS DE Tectona grandis CRESCENDO NA COSTA RICA}

RESUMO: A madeira de Tectona grandis é importante no mercado devido às suas excelentes características de trabalhabilidade, durabilidade e estética. Por isso é importante melhorar as condições de reprodução e do desenvolvimento das plantações comerciais utilizando clones com o objetivo de produzir árvores produtoras de madeira de boa qualidade. No presente estudo foram estudadas as propriedades gerais, físicas e a coloração da madeira de 20 clones de teca (20 anos de idade) da região de Guanacaste, Costa Rica. Os resultados indicaram que clones no $15^{\circ}$ ano atingem um diâmetro do tronco variando de 19,82 a 30,13 cm e a porcentagem de cerne de 49,76 a 60,02\%, ambas em valores similares aos reportados na literatura. Em relação às propriedades físicas da madeira, verificou-se que a massa especifica varia de 0,45 a $0,60 \mathrm{~g} \cdot \mathrm{cm}^{-3}$, o teor de umidade na condição verde de 70 a $110,6 \%$. Em relação à cor da madeira, os valores de L* variaram de 48 a 59, a* de 7 a 9,5 e b* de 20,5 a 26,3. Determinou-se que a coloração da madeira $\left(\Delta \mathrm{E}^{*}\right)$ em relação à da madeira comercial é comumente categorizada como perceptível para todos os clones. Entretanto, três dos clones estudados apresentaram madeira mais escura e tonalidade avermelhada que indica ser a coloração mais apreciada do usuário final. 


\section{INTRODUCTION}

Teak (Tectona grandis) has become one of the most important woods in the market due to its physical, mechanical and aesthetic qualities (KEOGH, 2009). Its coveted color, has allowed it to be one of the more important planting tropical species in the market (KOLLERT and CHERUBINI, 20I2). One aspect that has been observed in reforestation with this species, is that it is increasingly attractive to use clones in order to obtain greater profits in less time, resulting in greater volume and quality of the wood (MONTEUUIS and MAITRE, 2006). However, there is significant variability in certain important economic characteristics such as growth, shape and some technological and aesthetic wood properties (MONTEUUIS and MAITRE, 2006).

On the other hand, genetic improvement is important to improve the conditions of reproduction and development in commercial plantations in order to produce trees with better wood quality. This improvement is focused in incrementing the plantation productivity and many wood properties (NEALE and KREMER, 20I I).

Moreover, some research related to genetic improvement of $T$. grandis is oriented to the study of the shape and characteristics of the tree. Several authors (MONTEUUIS and MAITRE, 2006) mention that these phenotypic parameters and other characteristics of rectitude and insertion of tree branches are the main parameters used in the selection of individuals conducive for cloning, however cloning must be refined with the analysis of wood characteristics (MOYA et al., 2013). This situation has so far rarely been evaluated.

Some studies try to incorporate some concepts of quality wood, such as the heritability of heartwood, bark thickness and calcium and silica content, anatomical elements, durability of wood, wood color and wood density (KJ/ER et al., 1999). However it is noteworthy that these studies are mainly based on provenance and unrelated to the cloning of $T$. grandis. More recently Moya and Marin (20I I), Moya et al. (20I3) and Solorzano et al. (20I2a and 20l2b) have studied the effect of cloning trees and wood properties of younger trees (juvenile period).

For these reasons, the objective of this study is to determine the general properties (diameter, heartwood, bark and pith), physical (specific gravity, green density, tangential, radial and volumetric shrinkage) and color characteristics measured by the system CIELab of 20 adult clones of Tectona grandis growing in Costa Rica, also determining the variability of these characteristics in each clone.

\section{MATERIALS AND METHODS}

\section{Site description}

The plantation sampled is located in the province of Guanacaste, Costa Rica. This region has an average annual rainfall of $1750 \mathrm{~mm}$, average temperature of $27^{\circ} \mathrm{C}$ and a dry season of about 6 months (December to May). Soil texture is a clay loam texture, moderately acidic ( $\mathrm{pH} \mathrm{5-6)}$ is moderately fertile and has moderate organic matter content, flat terrain with a slope of less than 3\% (MOYA and MARIN, 20I I, MOYA et al. 20I3).

\section{Conditions of the plantation}

The plantation age was 15 years old at the time of sampling, which corresponds to a third commercial thinning. The experimental plantation consisted of 40 clones planted in five blocks, in which three individuals were available for each clone randomly distributed within the block, which means a total of 80 trees per block with spacing $3 \times 3 \mathrm{~m}$ between trees. The detail of the establishment of clonal experimental is detailed in Moya and Marin (20II) and Moya et al. (20I3). Also in these experimental plantations a thinning of about $50 \%$ was applied at the age of 5 years and a second thinning at the age of I I years with a genetic thinning of $20 \%$.

\section{Sampling of clones}

Twenty clones were selected from the 40 present since the remaining 20 did not have the amount of trees needed for sampling, this because they were not adapted to the site. For the selection of the trees to be sampled, one tree was selected from each of the clones from the first 3 blocks ( 3 trees in total). These trees were selected without damage by fungi and insects. From each tree sampled, two discs of $3 \mathrm{~cm}$ thickness at I. 3 meters height were obtained from the diameter at breast height $(\mathrm{DBH})$. 


\section{Determination of general properties}

A disk obtained from $\mathrm{DBH}$ were measured total diameter, heartwood diameter, pith diameter, sapwood thickness and bark thickness. These dimensions were measured on the disks in two directions, north-south and east-west. Then, the percentage of heartwood, bark and pith were calculated. All percentages were calculated using the total area of those tissues in relation to the total disk area expressed as a percentage. Also, the percentage of eccentricity of the pith was calculated, using for such, the methodology proposed by Akachuku and Aborin (1989).

\section{Determination of physical properties}

The properties determined were specific gravity, moisture content in green condition, green density volumetric radial and tangential shrinkage and ratio of tangential and radial shrinkage. To determine the physical properties a block was cut along the center of the disk and then it was cut in half to divide them into sub pieces.
With the leftover parts, samples for radial and tangential shrinkage were obtained. This pattern was used in these clones at the age of II years and is detailed in the study by Moya and Marin (20II) and Moya et al. (20I3). On the diametric section, weight and volume of the samples were determined in green condition and subsequently samples were dried in the oven at a temperature of $105^{\circ} \mathrm{C}$ for 24 hours to determine the weight and volume in dry conditions, these measures were performed according to the norm in accordance with the standard D-239502 (ASTM, 2003a). The values for weight and green volume and oven dry volume were used to calculate the green density, volumetric shrinkage, moisture content and specific gravity. For samples of radial and tangential shrinkage was used the D-I43 standard (ASTM, 2003b). Moisture content was measured according to D-I442 standard (ASTM, 2003d).

\section{Determination of color of the wood and determination $\Delta \mathrm{E}^{*}$}

The color was determined only in the heartwood of the cross-section, which was cut from

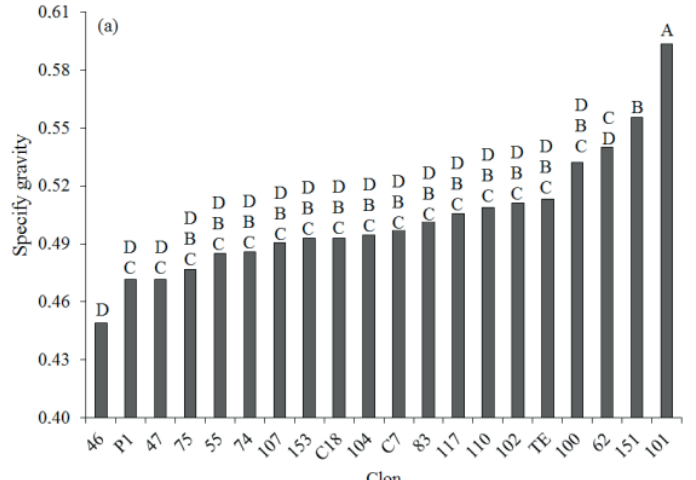

Clon
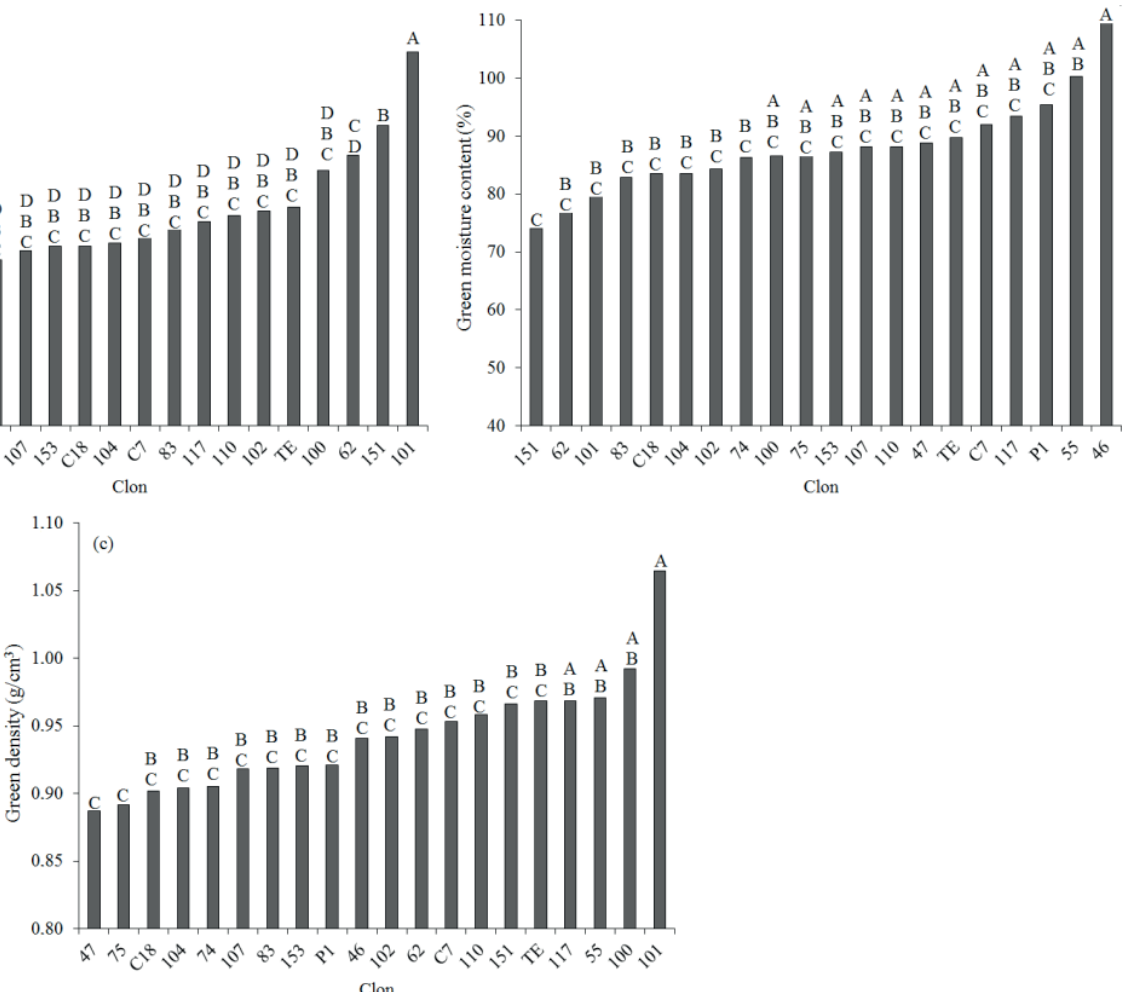

FIGURE 1 Specific gravity (a), green moisture content (b) and green density (c) for clones of Tectona grandis from a I5 year-old plantation in Costa Rica. FIGURA 1 Massa especifica (a), teor de umidade em condição verde e densidade verde (c) para clones de Tectona grandis de uma plantação de I5 anos na Costa Rica. 
$\mathrm{DBH}$. On this disk a diametrical section of $3 \mathrm{~cm}$ wide was extracted. Then, a block of $2 \times 2 \times 2 \mathrm{~cm}$ was cut at different distances: near the pith, in the middle of the radius of the heartwood and near the sapwood. A total of 480 samples ( 8 samples per disk $\times 3$ reps $\times 20$ clones) were extracted from the sampled trees. Wood color was determined on the block's tangential face in accordance with ASTM D-2244 (ASTM, 2005c). A HunterLab MiniScan ${ }^{\circledR}$ XE Plus spectrophotometer was used. Measurements were taken at room temperature and color characteristics were determined using CIELab system (parameters L*, $\mathrm{a}^{*}$, and $\mathrm{b}^{*}$ ) and according to Hunter Lab (1995). The wood color of heartwood was averaged from three different distances. Keey (2005) indicates that the difference between two wood samples measured by the CIE Lab system can be expressed as an index named $\Delta \mathrm{E}^{*}$, which establishes the difference between two points in the coordinates of the color system and is calculated by the sum of the squared difference for each in each of the coordinates (Equation I). In this work it was considered important to calculate $\Delta \mathrm{E} *$ value to evaluate the heartwood color quality of the clones studied. For this, it was taken as a reference or standard a color of the heartwood of $T$. grandis of 2 tables from an individual from the natural forest in Myanmar which was donated by the company Cabo Rico SA (http://www. caborico.com/) who uses the wood from this country on the deck of the sailboats it manufactures. To this table, color was measured with the conditions and parameters of the sampled trees. The standard values for $L^{*}, a *$ and $b *$ are 44.94, 12.44 and 24.26 respectively. The $L *$, $a *$ and $b *$ values were averaged for this pattern and then the $\Delta \mathrm{E} *$ was obtained (Equation I) proposed by ASTM D 2244 (ASTM, 2003c). Where: $\Delta \mathrm{L}^{*}=\Delta \mathrm{L}^{*} \mathrm{M}-\Delta \mathrm{L}^{*} \mathrm{P}$; $\Delta \mathrm{a}^{*}=\Delta \mathrm{a}^{* \mathrm{M}}-\Delta \mathrm{a}^{* \mathrm{P}} ; \Delta \mathrm{b}^{*}=\Delta \mathrm{b} * \mathrm{M}-\Delta \mathrm{b} * \mathrm{P} ; \mathrm{M}=$ value of the color coordinate of the sample, $\mathrm{P}=$ value of the color coordinate of the pattern

$$
\Delta \mathrm{E}=\sqrt{\left(\Delta \mathrm{L}^{*}\right)^{2}+\left(\Delta \mathrm{a}^{*}\right)^{2}+\left(\Delta \mathrm{b}^{*}\right)^{2}}
$$

\section{Statistical analysis}

Wood properties evaluated in each clone had mean values. Subsequently, an analysis of variance was conducted. Data normality was primary verified as well as the homogeneity of variance. The analysis of variance (ANOVA) of wood properties was established on the detailed model in Equation 2. SAS software (SAS Institute Inc) was used to carry out the statistical analysis. The difference between the means of the clones was established by the Tukey test at a significance of $99 \%$. Where: $Y_{i}$ is the observation of each wood property of the $i$ tree, $\mu$ is the overall mean, $c$ is the random effect of clone, and $i$ is the residual random effect.

$Y_{i}=\mu+c_{i}+e_{i}$

\section{RESULTS}

\section{General Characteristics}

The average values of the DHB vary from 19.82 $\mathrm{cm}$ to $30.13 \mathrm{~cm}$, the highest value corresponds to clone 100 and the lowest values are the clones 46 and TE (Table I). No significant difference in $\mathrm{DBH}$ was found in clone $100,75,83,104,117, \mathrm{CI} 8$ and 153. Whereas the lowest value only presents statistical differences with the clones 100, 104 and CI8. In relation to sapwood thickness, this varies from I.7 to $2.75 \mathrm{~cm}$, the lowest value corresponds to clone 46 and only differs significantly for clones 83 , $100,151,153, \mathrm{Cl} 8$ and C7. The highest value is the clone Cl 8 with a value of $2.75 \mathrm{~cm}$ and only presents statistical differences with the clone 46 (Table I). Heartwood diameter presents a range of $14.47 \mathrm{~cm}$ for clone TE to $23.92 \mathrm{~cm}$ for clone 100. Heartwood diameter of clone 100 has a value statistically equal to clones $83,104,1$ I 7 and CI8. Clone TE is statistically equal to the rest of the clones except for clones 100, 104 and II7. Heartwood diameter values vary from 49.76 to $60.02 \%$. The lowest value corresponds to the clone $15 \mathrm{I}$, however this value is only statistically different from clones 100, 104, 46 and II7. While the higher value corresponds to the clone 100 , which is only different from clones II0, 153 and TE. Bark thickness varies from $4.42 \mathrm{~cm}$ for clone 46 to $6.67 \mathrm{~cm}$ for clone $\mathrm{IOI}$ (Table I). Clone IOI is statistically different from the clones 46, 75, 100, II7, I53 and CI8, while clone 46 only differs from clone 10I. Percentage of bark varies from $6.23 \%$ to $12.30 \%$, clone 100 with the lowest value and clone I0I with the highest value. Clone 100 only shows difference with I0I, 102 and TE. Percentage of pith varied from 0.53 to $1.27 \mathrm{~cm}$ for the clones I $5 \mathrm{I}$ and $\mathrm{I} 00$ respectively. Clone I $5 \mathrm{I}$ has significant differences from clones 100 and II7 and clone 100 did not differ significantly from clones 47, 62, 83, 100, I04, 
II7, I53 and PI. In percentage of eccentricity of the pith, the variation was $3.42 \%$ for clone 83 to $15.66 \%$ for clone 100 , this differ significantly from the clones 47,62 , 74, 75, 83, I53, CI8 and PI (Table I).

\section{Physical Properties}

Specific gravity varied from 0.45 to 0.60 . Clone IOI has the highest value while clone 46 the lowest value (Figure Ia). Significant differences were found between clone $\mathrm{IOI}$ and the others except for clones 62 and I5I (Figure Ib). Although the clone I5I has the lowest moisture content values, this presents no significant differences with the remaining clones, except for clones 46 and 55 (Figure Ib). Regarding green density, the lowest value was $0.87 \mathrm{~g} \cdot \mathrm{cm}^{-3}$ found in clone 47 which differ significantly only from clones $55, \mathrm{TE}$,
100 and 101 , this last clone got the highest value, with around $1.06 \mathrm{~g} \cdot \mathrm{cm}^{-3}$ (Figure Ic).

Volumetric, radial and tangential shrinkage for all clones are shown in Figure 2. Volumetric shrinkage varies from $5.4 \%$ to $8.5 \%$, the lowest value is for clone 104 showing differences with clones 83 and I5I, these with higher values. Clone I5I has differences only with clone 104 (Figure 2a). Tangential shrinkage varied from I.8 to $3.2 \%$, the lowest value corresponds to clone 55 , which differs with clones 102, I5I, TE, I0I, 62, PI, CI8 and 83 . The highest value of shrinkage occurs in clone 83 and only differs with clones 55 and 75 (Figure 2b). For radial shrinkage, it is observed that the lowest value is clone 55 with I. $1 \%$ and the highest value is $2.7 \%$ for clone I0I. No significant differences between clone $10 \mathrm{I}$ and the others with the exception of clone 55 (Figure 2c). The ratio of shrinkage does not present differences

TABLE 1 General Properties of Tectona grandis clones fro 15 years-old plantation in Costa Rica.

TABELA 1 Propriedades gerais de clones de Tectona grandis de um plantio de I5 anos na Costa Rica.

\begin{tabular}{|c|c|c|c|c|c|c|c|c|c|}
\hline \multirow{2}{*}{ Clone } & \multirow{2}{*}{$\begin{array}{l}\text { Diameter } \\
\text { (cm) }\end{array}$} & \multirow{2}{*}{$\begin{array}{c}\text { Sapwood } \\
\text { thickness } \\
(\mathrm{cm})\end{array}$} & \multicolumn{2}{|c|}{ Heartwood } & \multicolumn{2}{|c|}{ Bark } & \multicolumn{3}{|c|}{ Pith } \\
\hline & & & $\begin{array}{l}\text { Diameter } \\
\text { (cm) }\end{array}$ & $\%$ & $\begin{array}{c}\text { Thickness } \\
\text { (mm) }\end{array}$ & $\%$ & $\begin{array}{l}\text { Diameter } \\
\text { (cm) }\end{array}$ & $\%$ & $\begin{array}{l}\text { Eccentricity } \\
\text { (\%) }\end{array}$ \\
\hline 46 & $19.8(23.0)^{\mathrm{D}}$ & $1.74(43.83)^{\mathrm{B}}$ & $15.5(19.1)^{\mathrm{CD}}$ & $61.6^{\mathrm{AB}}$ & $4.4(22.9)^{\mathrm{B}}$ & $8.9^{B C}$ & $0.63(9.12)^{c}$ & $0.11^{A B}$ & 7. $1^{A B C}$ \\
\hline 47 & $22.3(9.3)^{\mathrm{BCD}}$ & $2.2(10.1 \mathrm{I})^{\mathrm{A} . \mathrm{B}}$ & $16.8(13.8)^{B C D}$ & $56.0^{\mathrm{ABC}}$ & $5.7(15.5)^{\mathrm{AB}}$ & $9.9^{\mathrm{AB}}$ & $0.90(19.25)^{\text {A.B.C }}$ & $0.16^{\mathrm{AB}}$ & $3.9^{c}$ \\
\hline 55 & $22.1(11.0)^{\mathrm{BCD}}$ & $2.1(17.49)^{A . B}$ & $16.9(12.1)^{\mathrm{BCD}}$ & $58.5^{\mathrm{ABC}}$ & $5.2(5.6)^{\mathrm{AB}}$ & $9.2^{A B C}$ & $0.60(33.33)^{c}$ & $0.08^{\mathrm{B}}$ & $10.6^{\mathrm{ABC}}$ \\
\hline 62 & $22.6(10.6)^{\mathrm{BCD}}$ & $2.3(27.86)^{A . B}$ & $16.9(8.8)^{\mathrm{BCD}}$ & 56. $1^{A B C}$ & $5.7(17.8)^{\mathrm{AB}}$ & $9.9^{\mathrm{AB}}$ & $0.83(18.3)^{\mathrm{ABC}}$ & $0.14^{\mathrm{A} . \mathrm{B}}$ & $3.8^{c}$ \\
\hline 74 & $21.1(20.7)^{\mathrm{CD}}$ & $2.2(5.95)^{A . B}$ & I $5.7(25.93)^{C D}$ & $54.4^{\mathrm{ABC}}$ & $5.0(25.0)^{A B}$ & $9.3^{A B C}$ & $0.53(28.6)^{C}$ & $0.07^{B}$ & $5.5^{\mathrm{C}}$ \\
\hline 75 & $24.5(12.6)^{\mathrm{ABCD}}$ & $2.4(13.68)^{A . B}$ & $18.8(15.64)^{\mathrm{BCD}}$ & $58.6^{A B C}$ & $4.8(11.9)^{\mathrm{B}}$ & $7.8^{\mathrm{BC}}$ & $0.70(24.7)^{\mathrm{BC}}$ & $0.08^{A . B}$ & $5.5^{\mathrm{C}}$ \\
\hline 83 & $25.8(7.5)^{\mathrm{ABCD}}$ & $2.7(20.29)^{A}$ & $19.2(7.69)^{\mathrm{ABCD}}$ & $55.7^{A B C}$ & $5.9(12.2)^{A . B}$ & $9.0^{A B C}$ & $0.93(43.3)^{A B C}$ & $0.15^{A . B}$ & $3.4^{\mathrm{C}}$ \\
\hline 100 & $30.1(4.6)^{A}$ & $2.6(9.5 \mathrm{I})^{\mathrm{A}}$ & $23.9(4.4)^{\mathrm{A}}$ & $63.0^{\mathrm{A}}$ & $4.7(27.4)^{\mathrm{B}}$ & $6.2^{\mathrm{C}}$ & $1.27(19.9)^{\mathrm{A}}$ & $0.19^{A . B}$ & $15.7^{\mathrm{A}}$ \\
\hline 101 & $21.8(19.3)^{\mathrm{BCD}}$ & $2.1(22.05)^{A . B}$ & $16.3(20.2)^{C D}$ & $56.0^{A B C}$ & $6.7(28.1)^{A}$ & $12.1^{\mathrm{A}}$ & $0.67(22.9)^{\mathrm{BC}}$ & $0.1 I^{A B}$ & $15.4^{\mathrm{AB}}$ \\
\hline 102 & $21.4(17.30)^{\mathrm{DC}}$ & $2.1(22.3)^{A B}$ & $16.2(18.4)^{\mathrm{CD}}$ & $56.8^{A B C}$ & $5.3(12.6)^{A B}$ & $9.6^{A B}$ & $0.70(42.9)^{\mathrm{BC}}$ & $0.1 I^{A B}$ & $9.4^{A B C}$ \\
\hline 104 & $27.6(6.3)^{\mathrm{AB}}$ & $2.5(9.0)^{\mathrm{AB}}$ & $21.7(7.0)^{\mathrm{AB}}$ & $61.5^{\mathrm{AB}}$ & $5.0(10.0)^{A B}$ & $7.1^{B C}$ & $0.93(12.4)^{\mathrm{ABC}}$ & $0.12^{\mathrm{AB}}$ & $9.5^{\mathrm{ABC}}$ \\
\hline 107 & $22.7(\mid 4.1)^{\mathrm{BCD}}$ & $2.3(3.9)^{\mathrm{AB}}$ & $17.2(17.1)^{\mathrm{BCD}}$ & $56.7^{A B C}$ & $5.3(17.2)^{\mathrm{AB}}$ & $90^{A B C}$ & $0.77(41.9)^{\mathrm{BC}}$ & $0.12^{A B}$ & $7.4^{\mathrm{ABC}}$ \\
\hline 110 & $22.8(8.3)^{B C D}$ & $2.6(4.2)^{\mathrm{AB}}$ & $16.6(11.6)^{B C D}$ & $53.0^{\mathrm{BC}}$ & $5.1(24.3)^{A B}$ & $8.7^{B C}$ & $0.73(34.3)^{\mathrm{BC}}$ & $\left.0.1\right|^{A . B}$ & $9.9^{A B C}$ \\
\hline 117 & $25.5(18.3)^{\mathrm{ABCD}}$ & $2.3(55)^{\mathrm{AB}}$ & $19.9(23.9)^{\text {A.B.C }}$ & $60.2^{A B}$ & $4.7(8.2)^{B}$ & $7.3^{\mathrm{BC}}$ & I. $17(49.5)^{\mathrm{AB}}$ & $0.23^{\mathrm{A}}$ & $8.5^{A B C}$ \\
\hline 151 & $22.0(5.5)^{\mathrm{BCD}}$ & $2.7(7.2)^{\mathrm{A}}$ & $15.5(9.5)^{C . D}$ & $49.8^{A B C}$ & $5.3(16.5)^{A . B}$ & $9.3^{A B C}$ & $0.53(10.8)^{C}$ & $0.06^{\mathrm{B}}$ & $7.7^{\mathrm{ABC}}$ \\
\hline 153 & $25.2(11.7)^{\mathrm{ABCD}}$ & $2.7(22.7)^{A}$ & $18.9(10.8)^{B C D}$ & $56.2^{\mathrm{C}}$ & $4.8(10.5)^{\mathrm{B}}$ & $7.4^{\mathrm{BC}}$ & $0.93(22.3)^{A B C}$ & $0.15^{A B}$ & $5.6^{c}$ \\
\hline $\mathrm{CI} 8$ & $25.9(16.8)^{A B C}$ & $2.8(12.8)^{A}$ & $19.4(19.7)^{\mathrm{ABCD}}$ & $56.0^{A B C}$ & $4.8(10.8)^{\mathrm{B}}$ & $7.5^{\mathrm{BC}}$ & $0.77(32.8)^{\mathrm{BC}}$ & $0.10^{\mathrm{AB}}$ & $4.9^{c}$ \\
\hline $\mathrm{C7}$ & $23.3(16.3)^{\mathrm{BCD}}$ & $2.6(35.0)^{A}$ & $17.0(14.2)^{\mathrm{BCD}}$ & $53.8^{A B C}$ & $5.3(8.3)^{A B}$ & $9.0^{A B C}$ & $0.63(50.8)^{C}$ & $0.10^{A B}$ & $10.0^{A B C}$ \\
\hline $\mathrm{PI}$ & $21.8(1.5)^{B C D}$ & $2.2(12.2)^{A . B}$ & $16.28(2.0)^{\mathrm{CD}}$ & $56.0^{A B C}$ & $5.2(7.4)^{A B}$ & $9.3^{A B C}$ & $0.83(18.3)^{A . C}$ & $0.15^{A B}$ & $6.9^{\mathrm{BC}}$ \\
\hline TE & $19.8(4.4)^{\mathrm{D}}$ & $2.2(24.7)^{\mathrm{A} . \mathrm{B}}$ & $14.5(13.4)^{\mathrm{D}}$ & $53.3^{\mathrm{BC}}$ & $5.0(I 3.3)^{A B}$ & $9.8^{A B}$ & $0.77(32.8)^{\mathrm{BC}}$ & $0.16^{\mathrm{AB}}$ & $9.6^{\mathrm{ABC}}$ \\
\hline Average & $23.4(11.2)$ & $2.36(11.5)$ & $17.6(13.1)$ & 56.7 & $5.2(9.7)$ & 8.8 & $0.79(24.38)$ & 0.13 & 8.01 \\
\hline
\end{tabular}

The value in parenthesis represents standard deviation. 

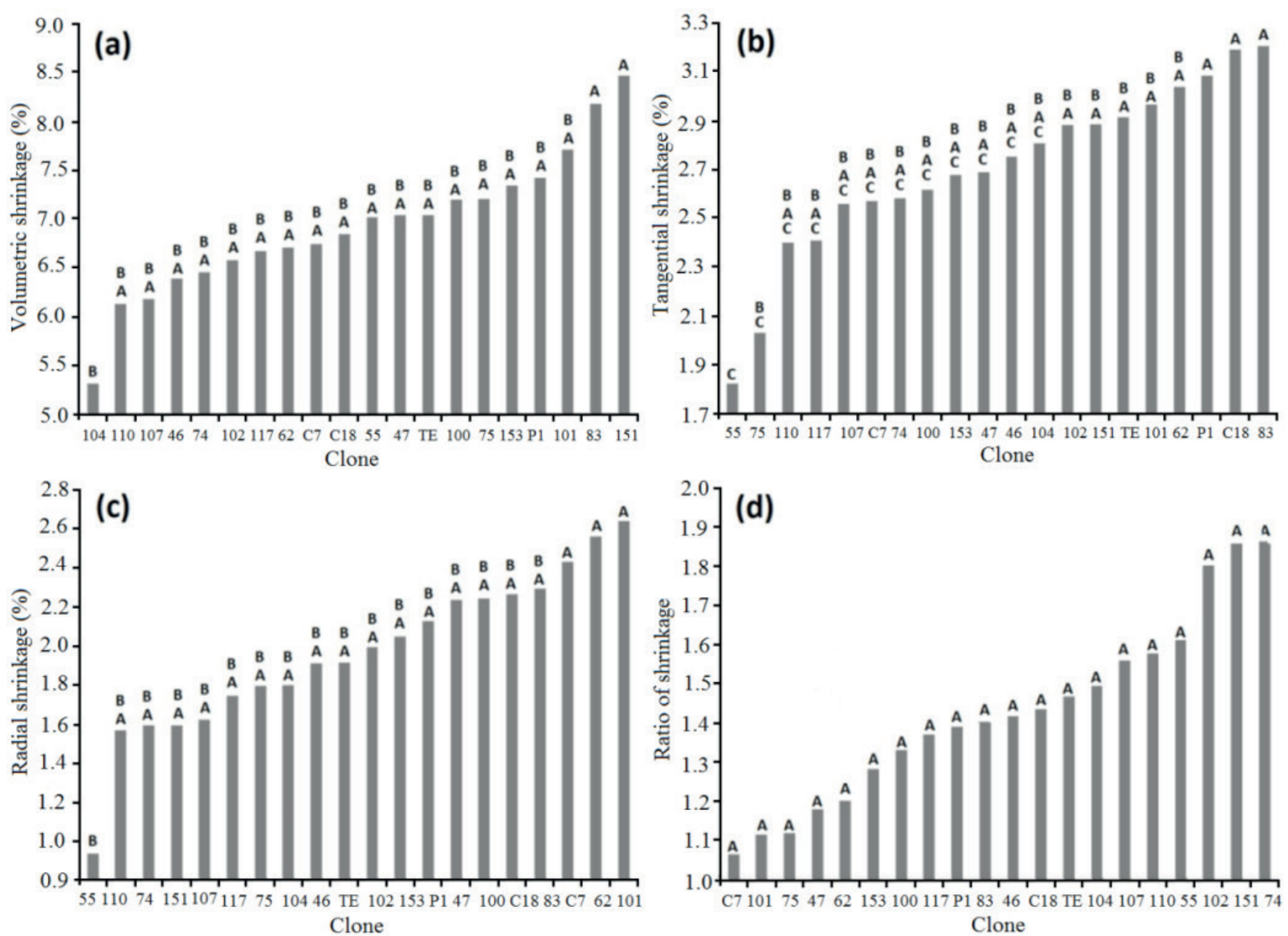

FIGURE 2 Volumetric shrinkage (a), tangential shrinkage (b), radial shrinkage (c), and ratio of shrinkage (d) for clones of Tectona grandis from a I5 year-old plantation in Costa Rica.

FIGURA 2 Retratilidade volumétrica (a), tangencial (c) e radial (c) e raio de retratilidades para clones de Tectona grandis de uma plantação de 15 anos na Costa Rica.

between any of the clones, presenting percentages that vary from 1.00 to I.86 (Figure $2 d$ ).

\section{Wood Color}

Figure 3 shows the results for the color difference $\left(\Delta \mathrm{E}^{*}\right)$ regarding the pattern of color, brightness $\left(\mathrm{L}^{*}\right)$, red (a*) and yellow (b*). $\Delta \mathrm{E}^{*}$ presents average values between 9 and 16 (Figure 3a). The lowest value is for clone $\mathrm{IOI}$ and the highest for 83 . Clone 83 has significant differences with PI, 55, I53, 75, 62, CI8, 107, I00, TE, 110 and 101 clones. The clone 101 differs with clones 104, C7, 102, 47, I5I, 46 and 83. Brightness values ( $\left.L^{*}\right)$, varied from 48 to 59 for clones $\mathrm{IOI}$ and 83 , respectively. The value for the clone 101 has no differences with clones TE, 107 and 110 (Figure 3b).

The parameter that measures redness $\left(\mathrm{a}^{*}\right)$ varied from 7.0 to 9.5 for clones 83 and 107 respectively. This last clone presents $a^{*}$ values statistically different with PI clones, I00, I5I, 47, I53, 74, C7, II7, 46 and 83. Yellow parameter (b*) values varied from 48 to 58 , the lowest value for clone $\mathrm{IOI}$ and the highest for clone 47. Clone 47 does not present statistically significant differences with clones 15I, 102, 55, C7, P, 117, 62, 46, 104 and 107. On the other hand, clone 101 did not present differences with clones $\mathrm{Cl} 8, \mathrm{TE}, 100,75,153$ and I IO (Figure 3d).

\section{DISCUSSION}

As expected, the study carried out by Moya and Marín (20II) and Moya et al. (20I3) with the same clones, but 4 years younger (II years) ha d the lower average $\mathrm{DBH}$ than the average $\mathrm{DBH}$ in the present study. For example, in the present study it was found that $\mathrm{DBH}$ varied from 19.82 to $30.13 \mathrm{~cm}$, and in the study with 4 years younger clones, the average DBH varied from 15.10 to $22.60 \mathrm{~cm}$. While heartwood percentage was on 

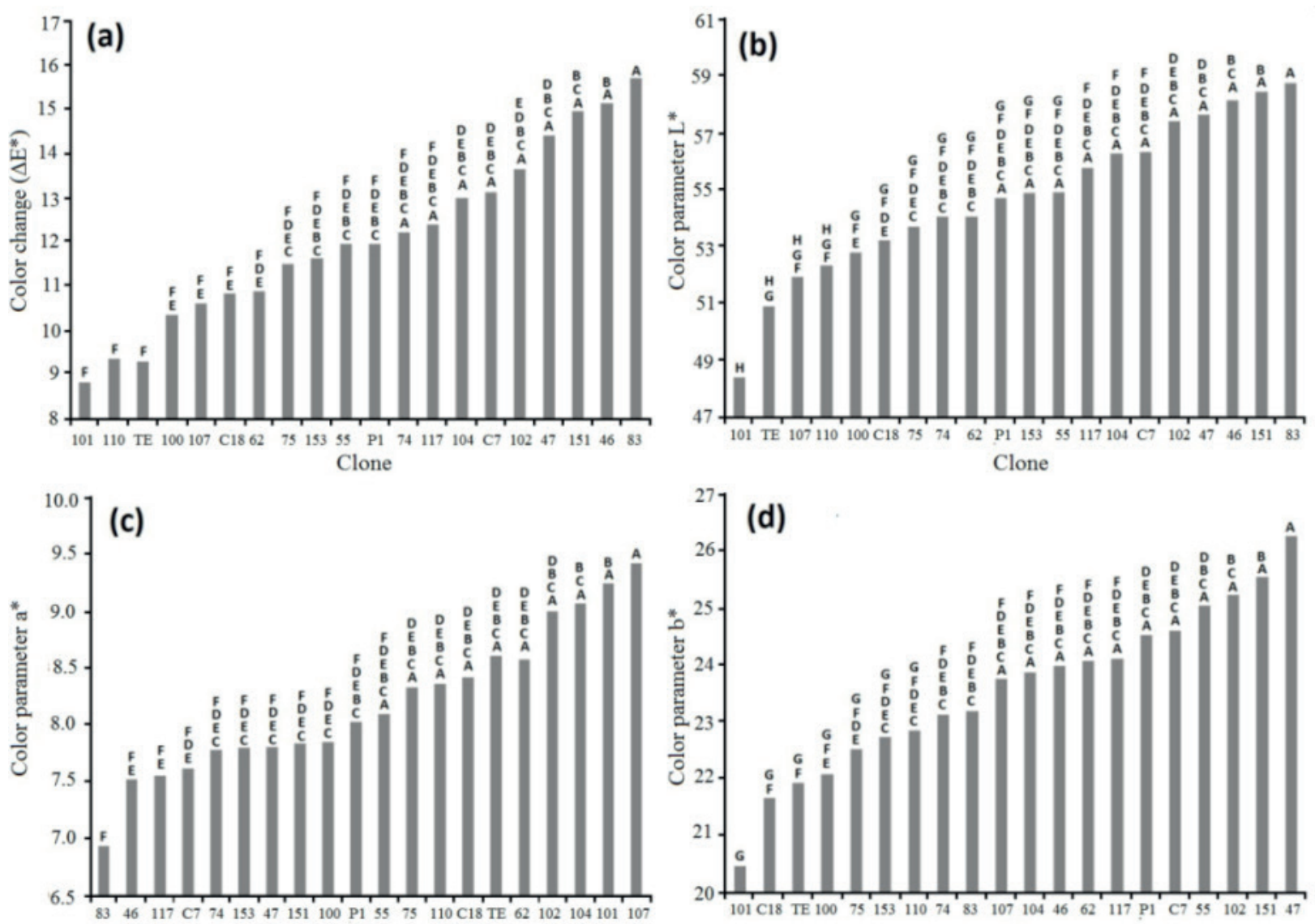

FIGURE 3 Color parameters for Tectona grandis clones from 15 years-old plantation in Costa Rica.

FIGURA 3 Parâmetros da cor da madeira para clones de Tectona grandis de um plantio de 15 anos na Costa Rica.

average $39.5 \%$ in the previous study (MOYA et al., 20I3) and at age of 15 years, the average of the clones was about $49 \%$, higher than the value obtained previously. In relation to bark percentage a significant reduction occurred, bark percentage at the age of 15 years varied from $6.23 \%$ to $12.30 \%$, while clones at age of II years reported a variation of 15.9 to $27.3 \%$. Finally, percentage of pith showed little variation between the different; the variation was from 0.23 to $0.70 \%$ to the current age, and from 0.0 to $0.5 \%$ when the trees were 4 years younger.

In the clones studied and considering $\mathrm{DBH}$, heartwood diameter and percentage of heartwood, it was found that the best overall $\mathrm{DBH}$ average values were obtained in clones number 100,75, 83, 104, I17, and $153 \mathrm{Cl}$, statistically the same (Table I). Having a high tree $\mathrm{DBH}$ allows better use of the log and reduces residues (QUIRÓS et al 2005), so the choice of clones with high $\mathrm{DBH}$ development will increase the use of logs of clones with highly developed DBH. By contrast, clones with low DBH development as clone TE, is expected to have small DBH logs and therefore have low yield. Regarding the heartwood, the clone that presents the largest heartwood diameter was clone 100, along with clones 83, 104, 117 and $\mathrm{Cl} 8$. At the same time, clone 100 showed the highest percentage of heartwood, although it is statistically similar to the rest of the clones except for II0, 156 and TE. Almost all clones presented more than $50 \%$ of percentage of heartwood, resulting as clones with potential for reforestation.

Regarding the pith, it can be observed that as the bark, percentage of pith was somewhat variable characteristic (Table I), especially for teak this is an important feature since the pith is very evident and is reflected directly into the timber (AKACHUKU and ABORIN, 1989). Eccentricity of the pith is important to take into account because ideally this should have low eccentricity within the tree to have a more uniform lumber in their dimension (MOYA et al, 2012). 
Analyzing the results of the different clones, it was noticed again that although clone 100 had desirable characteristics like high overall DBH and high percentage of heartwood, the same clone shows the highest values of eccentricity of the pith, while clones as the 83 had lower average in $\mathrm{DBH}$ but much lower eccentricity of the pith, which could turn into an advantage at the time of harvesting.

\section{Physical Properties}

Moya and Marin (20II) reported values of the physical properties for the same clones at II years of age. For the green moisture content and green density, the authors report values of $89.8 \%$ to $158.0 \%$ and of 1.0 and $1.2 \mathrm{~g} \cdot \mathrm{cm}^{-3}$, respectively. While in this study it was found values from $70 \%$ to $110.6 \%$ for the green moisture content and of

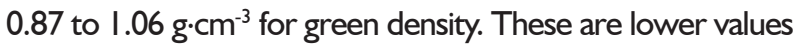
than indicated by Moya and Marin (20II). As to the values reported for shrinkage (volumetric, tangential and radial) the values found at the age of 15 are lower than those found at the age of II (MOYA and MARIN, 20I I). Indicating that the wood from the clones by increasing age of the trees become more dimensionally stable and they can present less warps during drying.

In relation to shrinkage, it is important that it occurs in low magnitude as these are related to the dimensional stability of wood (LEÓN, 20I0). Clone IIO is located within the lowest values for the three types of contraction (radial, tangential and volumetric) which indicates that it could have a good drying process with minimal deformation. Clone 55, despite having the lowest values in radial and tangential shrinkage, presents average values for volumetric shrinkage. Likewise, clones with mayor tangential shrinkage were clones 83 and I5I, therefore these clones probably present dimensional stability problems during drying. But these clones had high specify gravity, so high shrinkage is expected. For radial shrinkage, it can be observed on Figure $3 \mathrm{c}$ that only clone 55 had less than I.2\% shrinkage.

\section{Wood Color}

Moya and Marin (201I), reporting for the age of II years of these same clones, average color values for L* of 62.0 , for $\mathrm{a}^{*}$ values of 9.9 and $\mathrm{b}^{*}$ values of 29.5. These are slightly different from those found at the age of 15, which were 48-59, 7-9, 9.5 and 48-58, respectively. This comparison allows to observe that the color parameter $L *$ decreased, the parameter $\mathrm{a}^{*}$ was maintained and the parameter $\mathrm{b}^{*}$ increased. These variations in color parameters indicates that the clones decreased brightness and the tonality of color yellow increases, so color at the age of 15 years is s slightly darker than when the trees were II years old. This situation is expected since the color of the wood tends to be darker, because L* decreased and b* increased with tree age (MOYA and BERROCAL, 2010).

The color change $\left(\Delta \mathrm{E}^{*}\right)$ regarding the color pattern of teak is desirable if it has a low value. In the study of sampled clones, clones I0I, IIO and TE were highlighted. These have the lowest values of $\Delta \mathrm{E}^{*}$, due to low brightness values ( $\left.\mathrm{L}^{*}\right)$, high in red $\left(\mathrm{a}^{*}\right)$ and low values of yellow (b*) as a result darker colors. Wood with red tonalities (low values of $a^{*}$ ) and low brightness values (high values of $b^{*}$ ) produce darker colors (MOYA and BERROCAL, 20I0), resulting probably with wood visually appealing to the end-user.

In this study it was taken into consideration the value of color change $\left(\Delta \mathrm{E}^{*}\right)$. Cui et al (2004) defines color perception at various levels. Change value between 0 and 0.5 is defined as imperceptible; between 0.5 and $\mathbf{I . 5}$ as hardly perceptible; between I.5 and 3.0 is noticeable, between 3 and 6 as perceptible and between 6 and 12 as very perceptible. Considering this it can be seen that for all clones and for all distances, changes relative to the standard rate is greater than 8 , so the clones studied present a perceptible and very perceptible change regarding the natural color of teak growing in natural forests and the natural habitat of the species. Therefore, despite being a dark wood as mentioned earlier, is still far from the desirable color according to the color pattern.

\section{CONCLUSIONS}

The average values for the overall $\mathrm{DBH}$ and heartwood diameter were found within the literature for all clones and these values have increased with the age of the clones. It is also important to note that the clones 100, 75, 83, 104, I I 7, I 53 and $\mathrm{Cl} 8$ have favorable values in general properties, in particular the $\mathrm{DBH}$ and percentage of heartwood.

Values for the specify gravity and moisture 
content of some clones such as 62, $10 \mathrm{I}$ and $|5|$ are the highest and the lowest respectively. Simultaneously, clone 1 I 0 stands out due to the low rates of tangential, radial and volumetric shrinkage.

All clones studied and with the potential to reforest have different color to the wood that develops in the trees growing in natural habitat. However, the age of the clones has allowed the color to be darker at the age of 15 years, due to reduction in brightness $\left(L^{*}\right)$, and increases in tonalities of yellow (b*) and redness ( $\left.\mathrm{a}^{*}\right)$. This indicates that it can be marketable and desirable for different uses of commercial products.

Clones that showed better color characteristics such as low exchange value compared to wood that are commonly marketed are clones I0I, IIO and TE, because they have lower value of brightness $(L *)$, high values in red $(\mathrm{a} *)$ and averages values in yellow $(\mathrm{b} *)$.

\section{ACKNOWLEDGEMENTS}

The authors wish to thank to Vicerrectoría de Investigación y Extensión from Instituto Tecnológico de Costa Rica. Thanks to Precious Woods of Central America (MACORI) for supplying the wood samples for this study, mainly to Ing. Mario Espinoza Pizarro.

\section{REFERENCES}

AKACHUKU, A.E., ABOLARIN, D.A. Variations in the pith eccentricity and ring width in teak (Tectona grandis L.F.). Trees Structure and Function, Germany, v.3, n.2, p. I I II16, 1989.

AMERICAN SOCIETY FOR TESTING AND MATERIALS. ASTM D2395-02: standard test methods for specific gravity of wood and wood-base materials. Philadelphia, 2003a. (Annual Book of ASTM Standards, 04.10).

AMERICAN SOCIETY FOR TESTING AND MATERIALS. ASTM DI43-02: standard Test Methods for Small Clear Specimens of Timber. Philadelphia, 2003c. (Annual Book of ASTM Standards, 04.10).

AMERICAN SOCIETY FOR TESTING AND MATERIALS. ASTM D2244-02: standard practice for calculation of color tolerances and color differences from instrumentally measured color coordinates. Philadelphia, 2003c. (Annual Book of ASTM Standards, 04.10).

AMERICAN SOCIETY FOR TESTING AND MATERIALS. ASTM D-1442-92, Standard test methods for direct moisture content measurements of wood and wood-Base materials (Reproved 2003). Philadelphia, 2003d. (Annual Book of ASTM Standards, 04.10).

CUI,W; KAMDEM, P; RYPSTRA, T. Diffuse reflectance infrared fourier transform spectroscopy (DRIFT) and color changes of artificial weathered wood. Wood and Fiber Science, Madison, v.36, n.3., pp.29I-30I, 2004.

KEEY, RB. Colour development on drying. Maderas: Ciencia y Tecnología, Concepción, v.7, n. I, pp.3-16, 2005.

KEOGH R. The future of teak and the high-grade tropical hardwood sector: Planted forests and trees working paper FP/44E, FAO, Rome, Italy. 2009. Available at http://www. fao.org/forestry/site/I0368/en/

KJAER, ED; Kajornsrichon, S; Lauridsen, EB. Heartwood, calcium and silica content in five provenances of teak (Tectona grandis). Silvae Genetica, Germany, v.48, n.I, pp.I-3, 1999.

KOLLERT, W, CHERUBINI, L. Teak resources and market assessment. Planted Forests and Trees Working Paper FP/47/E, Rome, Italy. 2012. Available at http://www.fao. org/forestry/plantedforests/67508@I70537/en/

LEÓN, W. Anatomía y densidad o peso específico de la madera. Revista Forestal Venezolana, Merida, v.54, n. I, pp. 6776, 2010.

MONTEUUIS, O; MAÎTRE, H. Advances in teak cloning: New developments in teak cloning lead to better plantation stock. ITTO Tropical For update, Japon, v. I7, n.3, pp. I3I5, 2006.

MOYA, R; BERROCAL. A. Wood colour variation in sapwood and heartwood of young trees of Tectona grandis and its relationship with plantation characteristics, site, and decay resistance. Annual Forest Science, France, v.67, n.2, pp. 109-120, 2010.

MOYA, R.; MARÍN, B. Grouping of Tectona grandis (L.f.) clones using wood color and stiffness. New Forests, Germany, v.42, n.3, pp.329-345, $201 \mathrm{I}$.

MOYA, R; MARÍN, J.D; MURILLO, O; LEANDRO, L. Wood physical properties, color, decay resistance and stiffness in Tectona grandis clones with evidence of genetic control. Sivae Genetica, Germany v.62, n.3, 142-152, 2013.

MOYA, R.; TENORIO, C.; MEYER, I. Influence of wood anatomy on moisture content, shrinkage and drying defect in Vochysia guatemalensis Donn Sm. Scientia Florestalis, Piracicaba, v.40, n.94, pp. 249-258, 2012.

NEALE, D.B.; KREMER, A. Forest tree genomics: growing resources and applications. Nature Reviews Genetics, v. I2, n.2, pp. III-I22, 2012.

PÉREZ, D; KANNINEN, M. Heartwood, sapwood and bark content, and wood dry density of young and mature teak 
(Tectona grandis) trees grown in Costa Rica. Silva Fennica, Finland v.37, n. I, pp. 45-54, 2003.

QUIRÓS, R; CHINCHILLA, O; GOMEZ, M. 2005. Rendimiento en aserrío y procesamiento primario de madera proveniente de plantaciones forestales. Agronomía Costarricense, Costa Rica, v.29, n. 2, pp.7-I5, 2005.

SOLÓRZANO, S; MOYA, R; CHAUHAN, S. Early genetic evaluation of morphology and some wood properties of Tectona grandis $\mathrm{L}$ clones. Silvae genetica, Germany, v.6I, pp.58-65, 2012a

SOLÓRZANO, S; MOYA, R; MURILLO, O. Early prediction of basic density, shrinking, presence of growth stress, and dynamic elastic modulus based on the morphological tree parameters of Tectona grandis. Journal of Wood Science, Japan, v.58, n.3, pp. 290-299, 2012 b. 